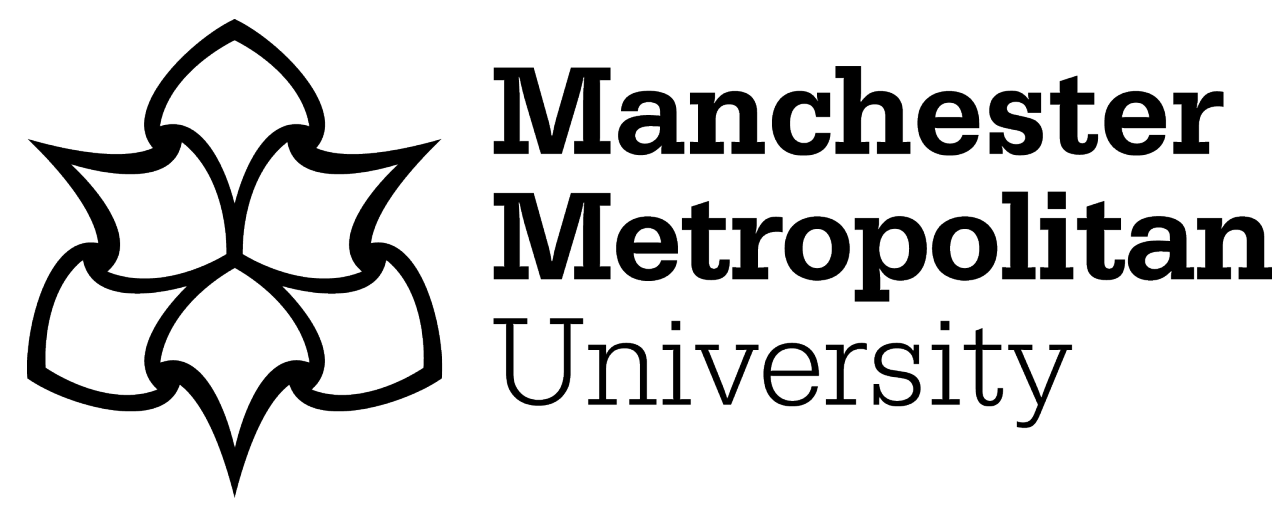

Stark, Christine H.E., Condron, Leo M., Stewart, Alison, Di, Hong Jie and O'Callaghan, Maureen (2007) Effects of past and current crop management on soil microbial biomass and activity. Biology and Fertility of Soils, 43 (5). pp. 531-540. ISSN 0178-2762

Downloaded from: https://e-space.mmu.ac.uk/8497/

Version: Accepted Version

Publisher: Springer

DOI: https://doi.org/10.1007/s00374-006-0132-3

Please cite the published version 


\title{
Effects of past and current crop management on soil microbial biomass and activity
}

\author{
Christine Stark $^{\mathrm{a}, \mathrm{b} *}$, Leo M. Condron ${ }^{\mathrm{b}}$, Alison Stewart ${ }^{\mathrm{c}}$, Hong J. Di ${ }^{\mathrm{b}}$, Maureen O’Callaghan ${ }^{\mathrm{d}}$
}

a,* Teagasc, Johnstown Castle, Wexford, Ireland. ph: +353 53 9171243; fax: +353 53 9142213; email: christine.stark@teagasc.ie

${ }^{\mathrm{b}}$ Agriculture \& Life Sciences Division, PO Box 84, Lincoln University, Lincoln 7647, New Zealand

${ }^{\mathrm{c}}$ National Centre for Advanced Bio-protection Technologies, PO Box 84, Lincoln University, Lincoln 7647, New Zealand

${ }^{\mathrm{d}}$ AgResearch, PO Box 60, Lincoln 7640, New Zealand

\begin{abstract}
As soil biota is influenced by a number of factors, including land use and management techniques, changing management practices could have significant effects on the soil microbial properties and processes. An experiment was conducted to investigate differences in soil microbiological properties caused by long- and short-term management practices. Intact monolith lysimeters $\left(0.2 \mathrm{~m}^{2}\right.$ surface area) were taken from two sites of the same soil type that had been under long-term organic or conventional crop management and were then subjected to the same $2 \frac{1}{2}-$-year crop rotation (winter barley (Hordeum vulgare L.), maize (Zea mais L.), lupin (Lupinus angustifolius L.) rape (Brassica napus L. ssp. oleifera)) and two fertiliser regimes (following common organic and conventional practices). Soil samples were taken after crop harvest and analysed for microbial biomass $\mathrm{C}$ and $\mathrm{N}$, microbial activity (fluorescein diacetate hydrolysis, arginine deaminase activity, dehydrogenase activity) and total $\mathrm{C}$ and $\mathrm{N}$. The incorporation of the green manure stimulated growth and activity of the microbial communities in soils of both management histories. Soil microbial properties did not show any differences between organically and conventionally fertilised soils, indicating that crop rotation and plant type had a larger influence on the microbial biomass and enzyme activities than fertilisation. Initial differences in microbial biomass declined, while the effects of farm management history were still evident in enzyme activities and total $\mathrm{C}$ and $\mathrm{N}$. Links between enzyme activities and microbial biomass $\mathrm{C}$ varied depending on treatment indicating differences in microbial community composition.
\end{abstract}

\section{Keywords}

Past and current management; Green manure; Intact monolith lysimeters; Soil microbial biomass; Microbial activity; Linkages

\section{Introduction}

In general, microbial biomass, enzyme activities, soil respiration, earthworm numbers and/or activity are found to be greater in soils under organic compared to conventional management (Wander et al., 1995; Shannon et al., 2002). In comparison, there is little evidence of negative effects of mineral fertiliser and pesticide use on the soil organic matter, microbial diversity and activity (Fraser et al., 1988; Gunapala et al., 1998). It is noted that other conventional practices may have different impacts on parts of the farm system (e.g. Kirchmann and Thorvaldsson, 2000). Most 
of these studies compared the use of organic matter inputs in one system with the addition of synthetic fertilisers in the other and the results strongly suggest that individual production techniques (e.g. green manuring and crop rotations) have a larger impact on the soil microbial community than the management system itself.

A lysimeter experiment was designed to evaluate the effect of farming history and current crop management practices on soil microbial properties and mineral $\mathrm{N}$ leaching (data not presented here). Intact monolith lysimeters were taken from two areas with organic and conventional farming histories under the same environmental conditions and the same soil type and were consequently subjected to the same crop rotation, which included a leguminous green manure crop. The practice of year round grazing in New Zealand is contrasting to European production systems, where livestock are overwintered inside producing large quantities of manure (Condron et al., 2000). This highlights the importance of green manure crops and the dependence on biological processes to supply sufficient amounts of $\mathrm{N}$ to crops especially in organic farming systems in New Zealand. However, including green manures in crop rotations is considered good management practice in any agricultural production system because of their many positive effects on soil fertility and quality (Doran et al., 1988; Watson et al., 2002).

In order to compare the effects of long-term organic and conventional management and current farming practices (crop rotation, green manuring, mineral and organic fertilisation) on the size and activity of the microbial community and to establish the relationships among soil microbiological properties in situ, soil samples were taken from the lysimeters after crop harvest and analysed for total $\mathrm{C}$ and $\mathrm{N}$, microbial biomass $\mathrm{C}$ and $\mathrm{N}$ and various enzyme activities that are commonly used as measures of microbial activity in soils.

\section{Materials and methods}

\section{Site description and lysimeter collection}

Eight intact monolith lysimeters were taken from each of two sites (approximately $2 \mathrm{~km}$ apart)

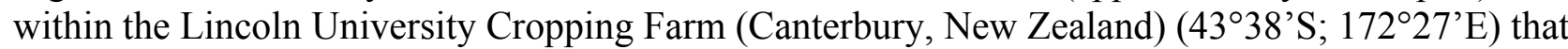
had the same soil type (Wakanui silt loam; Mottled Immature Pallic Soil, NZ classification; Udic Ustochrept, USDA) and similar chemical and physical topsoil properties. The sites had been farmed under contrasting organic (BHU) and conventional (LCF) management systems for 25 and over 100 years, respectively.

The BHU site was a low input area that had been under a six-year rotation until 1999 and had been under herb-ley (14 species including perennial ryegrass (Lolium perenne), lucerne (Medicago sativa) and white clover (Trifolium repens)) between 1999 and the time of sampling in 2001. There are no records of any inversion ploughing and most of the residues were left on the surface. The area had never been grazed, nor had it received any mineral fertilisers or pesticides.

The LCF site had been under pasture for almost 2 years when the lysimeters were taken in 2001 and prior to that had been under an 8-year. During the rotation, residues were incorporated to a depth of $15 \mathrm{~cm}$ by ploughing. The total average annual amount of $\mathrm{N}$ applied during the 8-year rotation was $70 \mathrm{~kg} \mathrm{~N} \mathrm{ha}^{-1}$, while a total of $16 \mathrm{~kg}$ phosphorus $(\mathrm{P}) \mathrm{ha}^{-1}$ year $^{-1}$ was applied.

The lysimeters were installed in the Lincoln University lysimeter laboratory according to the protocol established (Cameron et al., 1992), and for the following three years, four lysimeters from each site were managed under the original production system, while the other four were managed under the alternative management system, resulting in four treatments distinguished by farming history and current management practice (Fig. 1). The crop rotation was identical for all treatments 
(barley, followed by maize, a lupin green manure and rape) (Table 1), as were soil cultivation, irrigation, weed and pest control techniques.

\section{Soil sampling and analyses}

On four occasions (see Table 1 for details), soil samples were taken from the lysimeters after crop harvest using a sampling strategy developed previously (Stark et al., 2004). In brief, 11 soil cores $(0-15 \mathrm{~cm})$ were taken from each lysimeter, bulked and sieved $(4 \mathrm{~mm})$. All plant material and roots were removed and the samples were stored at $4^{\circ} \mathrm{C}$ for up to 5 days before analyses took place.

Microbial biomass $\mathrm{C}\left(\mathrm{C}_{\mathrm{mic}}\right)$ and $\mathrm{N}\left(\mathrm{N}_{\text {mic }}\right)$ were estimated using the fumigation-extraction technique (Sparling and West, 1988) which allows for microbial biomass $\mathrm{C}$ and $\mathrm{N}$ to be determined in the same extract and does not require for the soil microbial community to be in equilibrium (as required for substrate induced respiration) (Schinner et al., 1995). After extraction with $\mathrm{K}_{2} \mathrm{SO}_{4}$ (extraction ratio 1:4), total extractable $\mathrm{C}$ was determined on a TOC-5000 A analyser (Shimadzu) and total extractable $\mathrm{N}$ was measured by persulphate digestion following the method of Cabrera and Beare (1993). For conversion of total $\mathrm{C}$ and $\mathrm{N}$ to $\mathrm{C}_{\mathrm{mic}}$ and $\mathrm{N}_{\text {mic }}$, factors of $k_{\mathrm{eC}}=0.35$ (Sparling et al., 1990) and $k_{\mathrm{eN}}=0.54$ (Brookes et al., 1985) were used, respectively.

In addition, microbial activity was determined using three enzyme assays that are recognised as measures of the potential activity of the soil microbial community: arginine deaminase activity (ADA), dehydrogenase hydrolysis (DHH) activity and fluorescein diacetate (3', 6'diacetylfluorescein) hydrolysis (FDA). As dehydrogenase and ADA are only found in viable cells these enzyme assays are ideal measures for overall microbial activity in soils (Alef and Kleiner, 1986; Dick, 1992). FDA hydrolysis is carried out by a variety of enzymes (e.g. proteases, lipases and esterases) and the ability of the main decomposers to hydrolyse FDA has been recorded (Schnürer et al., 1985; Dick et al., 1996), however, both intra- and extracellular enzymes contribute to FDA hydrolysis.

ADA was determined using the method described by Alef and Kleiner (1987). $1.25 \mathrm{ml}$ of arginine solution $(0.2 \% \mathrm{w} / \mathrm{v})$ (sample) or deionised water (blank control) was added to $5 \mathrm{~g}$ of soil after preincubation $\left(15 \mathrm{~min}, 30^{\circ} \mathrm{C}\right)$. After $3 \mathrm{~h}$ of incubation at $30^{\circ} \mathrm{C}$, all samples were immersed in liquid $\mathrm{N}$ for 10 s to stop the reaction. Following extraction with $2 \mathrm{M} \mathrm{KCl}$ (extraction ratio 1:4), samples were filtered (Whatman No. 42) and ammonium-N $\left(\mathrm{NH}_{4}{ }^{+}-\mathrm{N}\right)$ concentration in the samples was determined by automated flow injection analysis (Tecator, Sweden).

FDA hydrolysis in the soils was determined according to Adam and Duncan (2001). Briefly, $15 \mathrm{ml}$ of $60 \mathrm{mM}$ potassium phosphate buffer ( $\mathrm{pH}$ 7.6) and FDA stock solution (samples only) were added to $2 \mathrm{~g}$ of field moist soil. After $20 \mathrm{~min}$ of incubation, the reaction was stopped by adding $15 \mathrm{ml}$ of chloroform/ methanol (2:1). Absorbance in the filtered solutions was measured at $490 \mathrm{~nm}$.

DHH activity was measured in the soil samples at all sampling dates using tris buffer ( $\mathrm{pH} 7.6)$ and triphenyltetrazolium chloride as substrate solution $(0.6 \% \mathrm{w} / \mathrm{v})$ (Thalmann, 1968). Five grams of field moist soil were incubated in $5 \mathrm{ml}$ of tris buffer with (sample) and without (blank) substrate solution for $16 \mathrm{~h}$ at $25^{\circ} \mathrm{C}$. After extraction with $25 \mathrm{ml}$ of acetone, samples and blanks were filtered and absorbance was measured at $546 \mathrm{~nm}$.

Total $\mathrm{C}\left(\mathrm{C}_{\text {tot }}\right)$ and $\mathrm{N}\left(\mathrm{N}_{\text {tot }}\right)$ were determined in air-dried and sieved samples $(2 \mathrm{~mm})$ on a Leco $\mathbb{}$ CNS-2000 elemental analyser. Ratios of total $\mathrm{C}$ to total $\mathrm{N}$ (C:N ratio), microbial $\mathrm{C}$ to microbial $\mathrm{N}$ (microbial C:N ratio or $\mathrm{CN}_{\text {mic }}$ ) and microbial $\mathrm{C}$ to total $\mathrm{C}$ (microbial quotient or $\mathrm{C}_{\text {mic }}: \mathrm{C}_{\text {tot }}$ ) were also determined from the data.

All analyses were carried out in triplicate. 


\section{Statistical analysis}

Data from all samplings except November 2003 were analysed by repeated measures analysis of variance, general linear model analysis of variance and correlation analysis using GenStat Release 7 (C2003, Lawes Agricultural Trust, Rothamsted Experimental Station, UK). Samples were considered significantly different when $\mathrm{p}<0.05$ and least significant differences $\left(\mathrm{LSD}_{0.05}\right)$ were calculated.

\section{Results}

\section{Influence of time on soil properties}

Differences among the four sampling dates were significant for most soil properties $(p<0.001)$ (except $\mathrm{C}_{\mathrm{tot}}$ ). In most cases, the highest levels of the respective soil parameter were measured at the first or second sampling. FDA was an exception with continuously increasing rates over time for all treatments (Fig. 2); the soil moisture content for all treatments was lowest in November 2003 (Table 2).

Relative differences between BHU and LCF samples were more pronounced than differences resulting from current management practices (organic [ORG] vs. conventional [CON] fertilisation) (Table 3). The large initial differences between BHU and LCF in microbial biomass C levelled out over time while they persisted in microbial activity (DHH, ADA and FDA) and total C (Fig. 3 and 4, Table 4).

In November 2003, microbial biomass $C$ was considerably lower and ADA higher than at the other three sampling dates and than the other parameters measured (Fig. 3a,d). Exclusion of the November 2003 data from the analyses lowered $\mathrm{LSD}_{0.05}$ and increased $\mathrm{p}$ values, but did not change the general trends for most soil properties. Correlations of microbial biomass $\mathrm{C}$ and ADA with soil moisture levels were determined by fitting the data to linear and quadratic regression functions, respectively. The quadratic regression for $\mathrm{C}_{\mathrm{mic}}-$ soil moisture gave a higher regression coefficient than a linear function $\left(\mathrm{R}^{2}=0.60\right.$ compared to 0.48 for a linear regression). Increasing levels of $\mathrm{C}_{\text {mic }}$ were observed with increasing soil moisture content while there was a weak, statistically significant negative correlation between soil moisture and ADA. However, as seen in Fig. 2, the extremely low microbial biomass C levels in November 2003 for treatments BHU-Org, BHU-Con and LCF-Org were statistical outliers and could not be explained with low soil moisture levels. The authenticity of the data was thoroughly assessed and verified, however, the reasons for their inconsistency compared with other results remained unclear.

\section{Influence of past management on soil properties}

Significantly higher rates of DHH $(\mathrm{p}<0.001)$ and ADA rates $(<0.001)$ and microbial quotient $(0.007)$ were measured in samples from BHU, while FDA $(<0.001)$ and $\mathrm{C}_{\text {tot }}(<0.001)$ were higher in LCF soils (Table 3). Actual differences in $\mathrm{C}_{\text {tot }}$ and microbial quotient were, however, small. These observations were the same for all sampling dates (Fig. 3 and 4).

For all soil properties, the relative differences between BHU and LCF samples remained consistent over time. No significant differences in $\mathrm{C}_{\text {mic }}, \mathrm{N}_{\text {mic }}, \mathrm{CN}_{\text {mic }}$ and $\mathrm{N}_{\text {tot }}$ were observed between $\mathrm{BHU}$ and LCF soil samples and BHU samples differed from LCF soils by factors between 0.95 and 1.05 at the different sampling dates, indicating that there were no differences based on management history in these properties. The biggest differences were measured in ADA and DHH, for which rates in 
LCF samples were around $65 \%$ of those measured in BHU samples, $\mathrm{N}_{\text {mic }}$ (LCF samples approximately $92 \%$ of BHU samples) and FDA (LCF samples $>120 \%$ of BHU samples).

\section{Influence of current management on soil properties}

Overall, DHH (0.005) and FDA activity (0.007) were significantly higher in ORG and CON samples, respectively, while the other soil properties did not show any significant differences based on current management (Table 4). Microbial C was initially (February 2003) significantly higher in soils from CON but these differences disappeared throughout the course of the experiment (Fig. 3a). Evaluation of the soil properties in ORG and CON samples relative to each other at each sampling date revealed only minor changes throughout the experiment and no obvious trends were observed, e.g. $\mathrm{C}_{\text {tot }}$ and $\mathrm{N}_{\text {tot }}$ levels in ORG samples ranged from 98 to $102 \%$ of levels in CON, while for ORG samples $\mathrm{N}_{\text {mic }}$ and $\mathrm{C}_{\text {mic }}$ levels were between 91 and $106 \%$ of CON samples at the different sampling dates. Only differences in ADA and FDA activity $(\mathrm{CON}>\mathrm{ORG})$ increased over time as a result of short-term management practices.

\section{Correlations among soil properties}

When excluding the November 2003 data from the analysis, the coefficients for correlations among the soil properties revealed the same general trends when assessed separately for the treatments (Tables 5 and 6). For example, highly positive correlations were observed among $\mathrm{C}_{\text {mic }}, \mathrm{N}_{\text {mic }}, \mathrm{DHH}$ and ADA, while FDA was negatively correlated to most other soil properties (except $\mathrm{C}_{\text {tot }}$, $\mathrm{N}_{\text {tot }}$ and $\mathrm{CN}_{\text {mic }}$ ). $\mathrm{C}_{\text {mic }}-\mathrm{C}_{\text {tot }}, \mathrm{C}_{\text {mic }}-\mathrm{N}_{\text {tot }}, \mathrm{N}_{\text {tot }}-\mathrm{C}_{\text {mic }}: \mathrm{C}_{\text {tot }}$ and $\mathrm{ADA}-\mathrm{CN}_{\text {mic }}$ were also negatively correlated. Unlike the other enzyme activities, $A D A$ did not show any correlations with $\mathrm{C}_{\text {mic }}$ and $\mathrm{C}_{\text {mic }}: \mathrm{C}_{\text {tot }}$.

While the overall tendencies were the same for all correlations, some differences could be observed in the level of significance of the links when comparing correlation coefficients of ORG with CON and BHU with LCF. For example, stronger correlations were detected between $\mathrm{CN}_{\text {mic }}$ and $\mathrm{ADA}$ and between $\mathrm{C}_{\text {mic }}: \mathrm{C}_{\text {tot }}$ and $\mathrm{DHH}$ for LCF and CON, respectively.

\section{Discussion}

As soil microbial properties are influenced by variations in soil moisture, temperature, crop type, nutrient supply, etc., as well as immediate farming practices, such as fertilisation and cultivation (Campbell et al., 1999) differences between the sampling dates were significant for most soil properties (except $\mathrm{C}_{\text {tot }}$ ). For most parameters, the highest values were measured after the first or second crop. This is consistent with the expected negative effects that cropping and repeated soil cultivation can have on soil organic matter content and soil microbial properties. Generally, lower levels of microbial activity and microbial biomass are found under arable cropping compared to pasture (Dick, 1992; Robertson and Morgan, 1996).

Only FDA hydrolysis increased during the experimental period and was highest at the last sampling point. Although associated with microbial activity, FDA hydrolysis is carried out by a range of enzymes including extracellular enzymes that can persist in the soil as part of inorganic complexes or when associated with organic colloids (Nannipieri et al., 2002). The increase in FDA hydrolysis activity may, therefore, indicate changes in soil properties that facilitate and protect extracellular enzymes or changes in the quantity and quality of root exudates that increase production of enzymes involved in hydrolysing FDA. There is no evidence in the literature linking FDA hydrolysis and root exudate quality or quantity, however, enzymatic activity of root exudates and the influence of exudates on enzyme production has been reported for other enzymes (Odunfa and Werner, 1981; Siciliano et al., 1998). These assumptions regarding the effects on FDA hydrolysis 
need to be confirmed in more detailed studies by determining the influence of different plant species and root exudates on enzyme activity.

The uncharacteristically low levels of microbial biomass $\mathrm{C}$ and associated ratios (microbial C:N and $\mathrm{C}_{\text {mic }}: \mathrm{C}_{\text {tot }}$ ) in November 2003 were difficult to explain. The lower soil moisture contents due to less frequent irrigation after lupin incorporation and the high temperature on the sampling date could have reduced the microbial biomass in November 2003 (Gunapala and Scow, 1998). The relatively higher rates of ADA (when compared with the other sampling dates), especially for BHUOrg which had the lowest levels of microbial biomass C, might support this theory and indicate a stress response of the microbial community (Nsabimana et al., 2004). Nsabimana et al. (2004) found that, similar to the metabolic quotient (ratio of respiration to microbial biomass), activity of arginine deaminase per unit of microbial biomass can serve as an indicator of disturbance or efficiency of the microbial community with higher levels indicating a less efficient, more stressed community (Wardle and Ghani, 1995). However, the lack of a correlation between soil moisture and ADA $\left(\mathrm{R}^{2}<0.1\right)$ contradicts the assumption and soil moisture levels could not account for all of the variation. The large variability within replicates for $\mathrm{C}_{\text {mic }}$, $\mathrm{ADA}$ and soil moisture in November 2003 could not be explained.

Changing (from organic to conventional management and vice versa) and adjusting management practices across the treatments (same crop rotation, cultivation, irrigation), should result in a decline of initially observed differences in microbial biomass and activity between the two sites as soil microbial communities are largely influenced by organic matter amendments and plant species that release root exudates of varying quantity and composition into the soil (Grayston et al., 1998; Lupwayi et al., 1998). In contrast, total $\mathrm{C}$ and $\mathrm{N}$ levels were expected to remain at the same levels, as they are considered more stable and less affected by changes in management practices in the short-term (Wander et al., 1995; Haynes, 1999).

At the end of the experimental period, ORG and CON samples and BHU and LCF samples, respectively, could not be distinguished from each other in terms of microbial biomass and total $\mathrm{C}$ and $\mathrm{N}$, while microbial activity (DHH, ADA and FDA) showed significant differences between treatments. This suggests that unlike enzymatic activity, microbial biomass was not affected by past management or short-term mineral fertilisation but by the management practices that were the same for all treatments (i.e. crop rotation and incorporation of green manure). These observations are in accordance with Gunapala et al. (1998), who reported no differences in microbial biomass $\mathrm{C}$ and $\mathrm{N}$ after the addition of organic material to soils that had been under long-term organic and conventional management, and with Bolton et al. (1985) who found that short-term mineral fertilisation did not affect the microbial biomass.

The difference between BHU and LCF samples in microbial activity after almost 3 years under the same crop rotation indicates that the influence of past management on enzymatic activities persisted over time. The differences in microbial activity between the two soils were observable even after addition (as for B-Con) or cessation of mineral fertilisation (as for L-Org), which indicates that some "residual activity" was present that did not respond quickly to changes in management practices and that the enzymatic activities were not affected by the addition of mineral fertilisers. Similarly, other studies emphasized the positive effects of organic matter addition but did not find a particular negative impact of fertilisation on microbial community size, i.e. biomass, and activity (e.g. Bolton et al., 1985; Fraser et al., 1988).

The difference in DHH activity between ORG and CON samples and BHU and LCF soils, respectively, could indicate either a positive effect of organic fertilisers or a negative effect of mineral fertilisation. The addition of the mineral fertiliser might have influenced DHH activity without affecting the size of the microbial community by inhibiting certain metabolic processes or microbial groups. Kumar and Tarafdar (2003), for example, suggested that DHH activity is mainly carried out by bacterial and actinomycete populations, while the contribution of fungal activity is usually limited. 
FDA hydrolysis and ADA, on the other hand, were higher in CON soils at most sampling points, with differences between treatments increasing over time. Other researchers reported increases in FDA hydrolysis as a result of organic amendments (e.g. Pfotzer and Schüler, 1995; Pankhurst et al., 2005). However, most of these studies compared the effects of mineral fertilisation in one treatment with organic amendments in the other treatment. The positive influence of mineral fertilisation on FDA hydrolysis activity seen in our study might be the result of indirect effects of increased plant and root biomass and activity that increased enzyme production (Doran et al., 1988).

The differences between ORG and CON in ADA suggest differences in the N cycle, in particular in $\mathrm{N}$ mineralisation, of the differently fertilised soil, which in turn indicates differences in microbial community structure. However, ADA rates did not follow any obvious trends during the trial period, which suggests that ADA might be subject to high seasonal variability. It is important to keep in mind that enzyme assays measure potential rather than actual activity and that enzymes can be bound to inorganic complexes or organic colloids and persist in soils for many years.

Measurements of enzyme activities under laboratory conditions are, therefore, only estimates of the actual activity of the enzyme in soils and over- as well as underestimation can occur (Dick, 1997; Nannipieri et al., 2002). The effects of mineral amendments on enzyme activities and individual microbial groups as well as the contribution of specific microbial communities to the enzyme activities need to be studied in more detail.

The correlations between microbial biomass and activity showed only minor differences when assessing past and current management effects separately. However, some differences in the strength of the correlations could be observed between the treatments, i.e. for some treatments microbial biomass was more closely related to activity levels (and vice versa) than for other treatments. This indicates that similarly sized microbial communities expressed varying rates of activity and that farming history as well as current management practices had an effect on certain aspects of the soil biota that could not be determined using the methodology chosen for this study. A likely explanation is the presence of differences in the microbial community composition as a result of past management and fertilisation strategy. It is possible that varying proportions of the microbial biomass were inactive, showed inefficient substrate use and that the enzyme activities were influenced by other, inherent soil factors.

The negative correlations of FDA with most other microbial soil properties (exception microbial $\mathrm{C}: \mathrm{N}$ ratio and total $\mathrm{C}$ and $\mathrm{N}$ ) are inconsistent with other researchers' observations (Haynes, 1999). Assuming that the FDA assay also measures activity of extracellular enzymes, which could account for the differences among the three enzyme activities. This supports the suggestion that FDA is not an accurate measure of microbial activity and emphasizes the importance of not relying on a single enzyme assay (Nannipieri et al., 2002). The strong negative correlation of FDA and $\mathrm{N}_{\text {mic }}$ indicates a relationship between this enzyme assay and $\mathrm{N}$ dynamics in the soil (Smith, 1994). This assumption is also supported by the increase of FDA hydrolysis in the treatments that received mineral fertiliser.

\section{Conclusions}

The decline in differences in the size of the microbial community in soils with organic and conventional farming histories suggests that the impact of crop rotation and green manuring (i.e. short-term management practices that were the same for all treatments) was greater than the effects of site history and mineral fertilisation. The incorporation of a lupin green manure stimulated the growth and activity of the microbial community, indicating that the microbial communities in both soils were adequate in size, composition and activity to respond to the addition of organic materials and that neither long-term organic nor conventional management had an inhibiting effect on the soil biota. DHH activity was consistently higher under organic and FDA under conventional fertilisation 
suggesting that these enzyme activities were negatively and positively affected by applying a mineral fertiliser, respectively. These assumptions need to be verified in more detail. Relationships between enzyme activities and microbial biomass $\mathrm{C}$ and $\mathrm{N}$ varied for the treatments indicating differences in microbial community compositions as a result of long- and short-term management, which could not be detected by the methods used in this study. This should be confirmed by determining the links between the enzyme activity and, for example, genetic diversity of selected microbial groups.

\section{Acknowledgements}

The authors are grateful for the technical assistance provided by Lincoln University Analytical Services. Special thanks to Andrew McLachlan for his advice regarding the statistical analysis of the data. We also wish to express our gratitude to Rhys Minchin, Neil Smith and Roger McLenaghen for practical help and advice. Financial support for this study was provided by the New Zealand Fertiliser Manufacturers' Research Association and Lincoln University.

\section{References}

Adam G, Duncan H (2001) Development of a sensitive and rapid method for the measurement of total microbial activity using fluorescein diacetate (FDA) in a range of soils. Soil Biol Biochem 33:943-951

Alef K, Kleiner D (1986) Arginine ammonification, a simple method to estimate microbial activity potentials in soils. Soil Biol Biochem 18:233-235

Alef K, Kleiner D (1987) Applicability of arginine ammonification as indicator of microbial activity in different soils. Biol Fert Soils 5:148-151

Bolton H, Jr., Elliott LF, Papendick RI, Bezdicek DF (1985) Soil microbial biomass and selected soil enzyme activities: effect of fertilization and cropping practices. Soil Biol Biochem 17:297-302

Brookes PC, Landman A, Pruden G, Jenkinson DS (1985) Chloroform fumigation and the release of soil nitrogen: a rapid extraction method to measure microbial biomass nitrogen in soil. Soil Biol Biochem 17:837-842

Cabrera ML, Beare MH (1993) Alkaline persulfate oxidation for determining total nitrogen in microbial biomass extracts. Soil Sci Soc Am J 57:1007-1012

Cameron KC, Smith NP, McLay CDA, Fraser PM, McPherson PJ, Harrison DF, Harbottle P (1992) Lysimeters without edge-flow: an improved design and sampling procedure. Soil Sci Soc Am J 56:1625-1628

Campbell CA, Biederbeck VO, Wen G, Zentner RP, Schoenau J, Hahn D (1999) Seasonal trends in soil biochemical attributes: effects of crop rotation in the semiarid prairie. Can J Soil Sci 79:73-84

Condron LM, Cameron KC, Di HJ, Clough TJ, Forbes EA, McLaren RG, Silva RG (2000) A comparison of soil and environmental quality under organic and conventional farming systems in New Zealand. NZ J Agr Res 43:443-466

Dick RP (1992) A review: long-term effects of agricultural systems on soil biochemical and microbial parameters. Agr Ecosyst Env 40:25-36 
Dick RP (1997) Soil enzyme activities as integrative indicators. In: Pankhurst CE, Doube BM, Gupta VVSR (eds.) Biological indicators of soil health. CAB International, Wallingford, UK, pp 144-156

Dick RP, Breakwell DP, Turco RF (1996) Soil enzyme activities and biodiversity measurements as integrative microbiological indicators. In: Doran JW, Jones AJ (eds.) Methods for assessing soil quality. Soil Science Society of America, Madison, USA, pp 247-271

Doran JW, Fraser DG, Culik MN, Liebhardt WC (1988) Influence of alternative and conventional agricultural management on soil microbial processes and nitrogen availability. Am J Alternative Agr 2:99-106

Fraser DG, Doran JW, Sahs WW, Lesoing GW (1988) Soil microbial populations and activities under conventional and organic management. J Env Qual 17:585-590

Grayston SJ, Wang S, Campbell CD, Edwards CA (1998) Selective influence of plant species on microbial diversity in the rhizosphere. Soil Biol Biochem 30:369-378

Gunapala N, Scow KM (1998) Dynamics of soil microbial biomass and activity in conventional and organic farming systems. Soil Biol Biochem 30:805-816

Gunapala N, Venette RC, Ferris H, Scow KM (1998) Effects of soil management history on the rate of organic matter decomposition. Soil Biol Biochem 30:1917-1927

Haynes RJ (1999) Size and activity of the soil microbial biomass under grass and arable management. Biol Fert Soils 30:210-216

Kirchmann H, Thorvaldsson G (2000) Challenging targets for future agriculture. Eur J Agron 12:145-161

Kumar P, Tarafdar JC (2003) 2,3,5-Triphenyltetrazolium chloride (TTC) as electron acceptor of culturable soil bacteria, fungi and actinomycetes. Biol Fert Soils 38:186-189

Lupwayi NZ, Rice WA, Clayton GW (1998) Soil microbial diversity and community structure under wheat as influenced by tillage and crop rotation. Soil Biol Biochem 30:1733-1741

Nannipieri P, Kandeler E, Ruggiero P (2002) Enzyme activities and microbiological and biochemical processes in soil. In: Burns RG, Dick RP (eds.) Enzymes in the environment. Marcel Dekker, Inc., New York, USA, pp 1-33

Nsabimana D, Haynes RJ, Wallis FM (2004) Size, activity and catabolic diversity of the soil microbial biomass as affected by land use. Appl Soil Ecol 26:81-92

Odunfa SA, Werner D (1981) Root exudates in relation to growth and nitrogenase activity of Rhizobium japonicum. Zeitschrift für Allgemeine Mikrobiologie 21:601-606

Pankhurst CE, Blair BL, Magarey RC, Stirling GR, Bell MJ, Garside AL (2005) Effect of rotation breaks and organic matter amendments on the capacity of soils to develop biological suppression towards soil organisms associated with yield decline of sugarcane. Appl Soil Ecol 28:271-282

Pfotzer GH, Schüler C (1995) Effects of different compost amendment on soil biotic and faunal feeding activity in an organic farming system In: Raupp J (ed.). Main effects of various organic and mineral fertilization on soil organic matter turnover and plant growth (Fertilization systems in organic farming [concerted action AIR3-CT94-1940]). Darmstadt, Germany. Institute for Biodynamic Research, pp 37-41

Robertson FA, Morgan WC (1996) Effects of management history and legume green manure on soil microorganisms under 'organic' vegetable production. Austr J Soil Res 34:427-440

Schinner F, Öhlinger R, Kandeler E, Margesin R (1995) Methods in soil biology. Springer Verlag, Berlin, Germany 
Schnürer J, Clarholm M, Rosswall T (1985) Microbial biomass and activity in an agricultural soil with different organic matter contents. Soil Biol Biochem 17:611-618

Shannon D, Sen AM, Johnson DB (2002) A comparative study of the microbiology of soils managed under organic and conventional regimes. Soil Use Manage 18:274-283

Siciliano SD, Goldie H, Germida JJ (1998) Enzymatic activity in root exudates of Dahurian wild rye (Elymus dauricus) that degrades 2-chlorobenzoic acid. J Agr Food Chem 46:5-7

Smith JL (1994) Cycling of nitrogen through microbial activity. In: Hatfield JL, Stewart BA (eds.) Soil Biology: Effects on Soil Quality. Lewis Publishers, Boca Raton, USA, pp 91-120

Sparling GP, Feltham CW, Reynolds J, West AW, Singleton P (1990) Estimation of soil microbial $\mathrm{C}$ by a fumigation-extraction method: use on soils of high organic matter content, and a reassessment of the $k_{\mathrm{ec}}$-factor. Soil Biol Biochem 22:301-307

Sparling GP, West AW (1988) Modifications to the fumigation extraction technique to permit simultaneous extraction and estimation of soil microbial C and N. Commun Soil Sci Plant Anal 19:327-344

Stark CHE, Condron LM, Stewart A, Di HJ, O'Callaghan M (2004) Small-scale spatial variability of selected soil biological properties. Soil Biol Biochem 36:601-608

Thalmann A (1968) Zur Methodik der Bestimmung der Dehydrogenaseaktivität im Boden mittels Triphenyltetrazoliumchlorid (TTC). Landw Forsch 21:249-250

Wander MM, Hedrick DS, Kaufman D, Traina SJ, Stinner BR, Kehrmeyer SR, White DC (1995) The functional significance of the microbial biomass in organic and conventionally managed soils. Plant Soil 170:87-97

Wardle DA, Ghani A (1995) Why is the strength of relationships between pairs of methods for estimating soil microbial biomass often so variable? Soil Biol Biochem 27:821-828

Watson CA, Atkinson D, Gosling P, Jackson LR, Rayns FW (2002) Managing soil fertility in organic farming systems. Soil Use Manage 18:239-247 
Table 1 Cultivars, management practices and fertilisation (NPKS in $\mathrm{kg} \mathrm{ha}^{-1}$ ) for crops grown in lysimeters.

\begin{tabular}{lllll}
\hline & Barley & Lupin & Maize & Rape \\
\hline Cultivar & County & Fest & Elita (hybrid) & Winfred \\
Sowing rate $\left(\mathrm{kg} \mathrm{ha}^{-1}\right)$ & 120 & 200 & 50 & 3 \\
Sowing date & 23 May 02 & 09 Mar 03 & 11 Nov 03 & 03 Apr 04 \\
$\begin{array}{l}\text { Harvest or } \\
\text { incorporation date }\end{array}$ & 29 Jan 03 & 18 Sep 03: app. 400 kg N & 08 Mar 04 & 19 Oct 04 \\
NPKS fertilisation & & ${\text { ha }{ }^{-1} \text { added to all treatments }}$ & & \\
\multicolumn{1}{c}{ CON } & $120 / 35 / 35 / 27$ & not fertilised & $80 / 27 / 27 / 21$ & not fertilised \\
\multicolumn{1}{c}{ ORG } & $0 / 35 / 35 / 27$ & not fertilised & $0 / 27 / 27 / 21$ & not fertilised \\
Date & Aug 02 & n/a & Nov 03 & n/a \\
\hline
\end{tabular}

Table 2 Mean soil moisture content (\%) determined for the four sampling dates in the lysimeter soils. Standard errors of means in parentheses. $\mathrm{n}=8$.

\begin{tabular}{lllll}
\hline Treatments & Feb-03 & Nov-03 & Mar-04 & Oct-04 \\
\hline BHU-Con & $22.5(1.84)$ & $16.5(0.34)$ & $20.6(0.15)$ & $22.9(0.53)$ \\
BHU-Org & $22.0(0.96)$ & $17.2(0.38)$ & $21.3(0.56)$ & $23.0(1.04)$ \\
LCF-Con & $21.7(0.36)$ & $19.1(0.58)$ & $19.5(0.92)$ & $22.6(0.91)$ \\
LCF-Org & $23.7(1.69)$ & $18.8(0.26)$ & $21.6(0.52)$ & $24.7(0.72)$ \\
\hline
\end{tabular}

Table 3 Overall mean effect of past organic (BHU) and conventional (LCF) management on soil properties determined over $2 \frac{1}{2}$ years. Values are means of two treatments and three sampling dates (standard errors of means in parentheses). $\mathrm{n}=72$.

\begin{tabular}{lllll}
\hline Soil property & BHU & LCF & F value & p value \\
\hline $\mathrm{C}_{\text {mic }}\left(\mu \mathrm{g} \mathrm{C} \mathrm{g}^{-1}\right)$ & $533(20.0)$ & $524(18.1)$ & 0.43 & $\mathrm{NS}$ \\
$\mathrm{N}_{\text {mic }}\left(\mu \mathrm{g} \mathrm{N} \mathrm{g}^{-1}\right)$ & $53.3(2.52)$ & $49.9(2.55)$ & 2.50 & $\mathrm{NS}$ \\
$\mathrm{DHH}\left(\mu \mathrm{g} \mathrm{TPF} \mathrm{g}^{-1} \mathrm{~h}^{-1}\right)$ & $6.75(0.616)$ & $4.76(0.437)$ & 73.0 & $<0.001$ \\
$\mathrm{FDA}\left(\mu \mathrm{g} \mathrm{fluorescein} \mathrm{g}^{-1} \mathrm{~h}^{-1}\right)$ & $194(9.67)$ & $236(11.2)$ & 123.4 & $<0.001$ \\
$\mathrm{ADA}\left(\mu \mathrm{g} \mathrm{NH}_{4}{ }^{-}-\mathrm{N} \mathrm{g}^{-1} \mathrm{~h}^{-1}\right)$ & $3.19(0.112)$ & $2.04(0.089)$ & 2.16 & $<0.001$ \\
$\mathrm{C}_{\text {mic }}: \mathrm{C}_{\text {tot }}(\%)$ & $1.92(0.075)$ & $1.80(0.063)$ & 10.3 & 0.007 \\
$\mathrm{CN}_{\text {mic }}$ & $10.3(0.420)$ & $10.8(0.426)$ & 1.22 & $\mathrm{NS}$ \\
$\mathrm{C}_{\text {tot }}(\%)$ & $2.79(0.019)$ & $2.92(0.018)$ & 34.3 & $<0.001$ \\
$\mathrm{~N}_{\text {tot }}(\%)$ & $0.229(0.002)$ & $0.232(0.002)$ & 1.11 & $\mathrm{NS}$ \\
\hline
\end{tabular}


Table 4 Overall mean effect of current organic (ORG) and conventional (CON) management on soil properties determined over $2 \frac{1}{2}$ years. Values are means of two treatments and three sampling dates (standard errors of means in parentheses). $n=72$.

\begin{tabular}{lllll}
\hline Soil property & ORG & CON & F value & p value \\
\hline $\mathrm{C}_{\text {mic }}\left(\mu \mathrm{g} \mathrm{C} \mathrm{g}^{-1}\right)$ & $532.4(15.8)$ & $523.9(21.9)$ & 0.41 & $\mathrm{NS}$ \\
$\mathrm{N}_{\text {mic }}\left(\mu \mathrm{g} \mathrm{g} \mathrm{g}^{-1}\right)$ & $52.0(2.65)$ & $51.3(2.46)$ & 0.12 & $\mathrm{NS}$ \\
$\mathrm{DHH}\left(\mu \mathrm{g} \mathrm{TPF} \mathrm{g}^{-1} \mathrm{~h}^{-1}\right)$ & $6.15(0.553)$ & $5.35(0.580)$ & 11.8 & 0.005 \\
$\mathrm{FDA}\left(\mu \mathrm{g} \mathrm{fluorescein} \mathrm{g}^{-1} \mathrm{~h}^{-1}\right)$ & $205(10.3)$ & $224(12.0)$ & 24.6 & 0.007 \\
$\mathrm{ADA}\left(\mu \mathrm{g} \mathrm{NH}_{4}^{+}-\mathrm{N} \mathrm{g}^{-1} \mathrm{~h}^{-1}\right)$ & $2.73(0.164)$ & $2.56(0.155)$ & 2.40 & $\mathrm{NS}$ \\
$\mathrm{C}_{\text {mic }}: \mathrm{C}_{\text {tot }}(\%)$ & $1.87(0.058)$ & $1.85(0.081)$ & 0.20 & $\mathrm{NS}$ \\
$\mathrm{CN}_{\text {mic }}$ & $10.6(0.456)$ & $10.5(0.395)$ & 0.11 & $\mathrm{NS}$ \\
$\mathrm{C}_{\text {tot }}(\%)$ & $2.86(0.022)$ & $2.84(0.024)$ & 1.04 & $\mathrm{NS}$ \\
$\mathrm{N}_{\text {tot }}(\%)$ & $0.231(0.002)$ & $0.230(0.002)$ & 0.01 & $\mathrm{NS}$ \\
\hline
\end{tabular}

Table 5 Correlation coefficients determined among soil properties in BHU and LCF soils in lysimeters. Levels of significance: ***, $\mathrm{p}<0.001 ; * *, \mathrm{p}<0.01$; $^{*}, \mathrm{p}<0.05 . \mathrm{n}=28$.

\begin{tabular}{|c|c|c|c|c|c|c|c|c|}
\hline & $\mathrm{C}_{\text {mic }}$ & $\mathrm{N}_{\text {mic }}$ & DHH & FDA & $\mathrm{ADA}$ & $\mathrm{C}_{\text {tot }}$ & $\mathrm{N}_{\text {tot }}$ & $\mathrm{C}_{\text {mic }}: \mathrm{C}_{\text {tot }}$ \\
\hline \multicolumn{9}{|l|}{ BHU } \\
\hline $\mathrm{N}_{\text {mic }}$ & $0.57 * *$ & & & & & & & \\
\hline $\mathrm{DHH}$ & $0.52 *$ & $0.79 * * *$ & & & & & & \\
\hline FDA & $-0.63 * * *$ & $-0.79 * * *$ & $-0.91 * * *$ & & & & & \\
\hline $\mathrm{ADA}$ & 0.13 & $0.44 *$ & $0.47^{*}$ & -0.25 & & & & \\
\hline $\mathrm{CN}_{\text {mic }}$ & 0.31 & $-0.59 * *$ & -0.42 & 0.30 & $-0.47^{*}$ & & & \\
\hline $\mathrm{C}_{\text {tot }}$ & -0.27 & -0.09 & 0.10 & 0.06 & 0.17 & -0.24 & & \\
\hline $\mathrm{N}_{\text {tot }}$ & $-0.51^{*}$ & -0.26 & -0.16 & 0.27 & 0.22 & -0.26 & $0.82 * * *$ & \\
\hline $\mathrm{C}_{\text {mic }}: \mathrm{C}_{\text {tot }}$ & $0.99 * * *$ & $0.56^{* *}$ & $0.47 *$ & $-0.60 * *$ & 0.09 & 0.33 & $-0.42 *$ & $-0.62 * *$ \\
\hline \multicolumn{9}{|l|}{$\mathrm{LCF}$} \\
\hline $\mathrm{N}_{\text {mic }}$ & $0.63 * * *$ & & & & & & & \\
\hline $\mathrm{DHH}$ & $0.40 *$ & $0.82 * * *$ & & & & & & \\
\hline FDA & $-0.40^{*}$ & $-0.80 * * *$ & $-0.93 * * *$ & & & & & \\
\hline $\mathrm{ADA}$ & 0.01 & 0.30 & 0.35 & -0.21 & & & & \\
\hline $\mathrm{CN}_{\text {mic }}$ & 0.17 & $-0.65 * * *$ & $-0.62 * * *$ & $0.62 * * *$ & -0.35 & & & \\
\hline $\mathrm{C}_{\text {tot }}$ & 0.10 & -0.21 & -0.25 & 0.26 & -0.02 & $0.36^{*}$ & & \\
\hline $\mathrm{N}_{\text {tot }}$ & -0.54 & $-0.54 * *$ & $-0.36^{*}$ & $0.40^{*}$ & 0.10 & 0.15 & $0.58^{* *}$ & \\
\hline $\mathrm{C}_{\text {mic }}: \mathrm{C}_{\text {tot }}$ & $0.98 * * *$ & $0.68 * * *$ & $0.45^{*}$ & $-0.45^{*}$ & 0.01 & 0.09 & -0.10 & $-0.66 * * *$ \\
\hline
\end{tabular}


Table 6 Correlation coefficients determined among soil properties of ORG and CON samples in lysimeters. Levels of significance: ${ }^{* *}, \mathrm{p}<0.001 ; * *, \mathrm{p}<0.01 ; *, \mathrm{p}<0.05 . \mathrm{n}=28$.

\begin{tabular}{|c|c|c|c|c|c|c|c|c|}
\hline & $\mathrm{C}_{\text {mic }}$ & $\mathrm{N}_{\text {mic }}$ & DHH & FDA & ADA & $\mathrm{C}_{\text {tot }}$ & $\mathrm{N}_{\text {tot }}$ & $\mathrm{C}_{\mathrm{mic}}: \mathrm{C}_{\mathrm{tot}}$ \\
\hline \multicolumn{9}{|l|}{ ORG } \\
\hline $\mathrm{N}_{\text {mic }}$ & $0.52 * *$ & & & & & & & \\
\hline DHH & 0.26 & $0.89 * * *$ & & & & & & \\
\hline FDA & $-0.38^{*}$ & $-0.81 * * *$ & $-0.88 * * *$ & & & & & \\
\hline $\mathrm{ADA}$ & -0.08 & $0.48^{*}$ & $0.65^{* * *}$ & -0.60 & & & & \\
\hline $\mathrm{CN}_{\text {mic }}$ & 0.16 & $-0.75 * * *$ & $-0.80 * * *$ & $0.64 * * *$ & $-0.59 * *$ & & & \\
\hline $\mathrm{C}_{\text {tot }}$ & -0.10 & -0.24 & -0.29 & $0.49 *$ & $-0.45^{*}$ & 0.19 & & \\
\hline $\mathrm{N}_{\text {tot }}$ & $-0.56^{* *}$ & $-0.42 *$ & -0.31 & $0.52 * *$ & 0.04 & 0.04 & $0.70 * * *$ & \\
\hline $\mathrm{C}_{\text {mic }}: \mathrm{C}_{\text {tot }}$ & $0.96 * * *$ & $0.55^{* *}$ & 0.32 & $-0.49^{*}$ & 0.04 & 0.10 & -0.38 & $-0.73 * * *$ \\
\hline \multicolumn{9}{|l|}{$\mathrm{CON}$} \\
\hline $\mathrm{N}_{\text {mic }}$ & $0.67 * * *$ & & & & & & & \\
\hline DHH & $0.63 * *$ & $0.72 * * *$ & & & & & & \\
\hline FDA & $-0.60 * *$ & $-0.80 * * *$ & $-0.93 * * *$ & & & & & \\
\hline $\mathrm{ADA}$ & 0.22 & 0.26 & $0.54 * *$ & $-0.41 *$ & & & & \\
\hline $\mathrm{CN}_{\text {mic }}$ & 0.30 & $-0.49 *$ & -0.22 & 0.37 & -0.12 & & & \\
\hline $\mathrm{C}_{\text {tot }}$ & -0.18 & -0.22 & -0.23 & 0.27 & $-0.44^{*}$ & 0.08 & & \\
\hline $\mathrm{N}_{\text {tot }}$ & $-0.52 *$ & -0.36 & -0.23 & 0.23 & -0.03 & -0.18 & $0.62 * *$ & \\
\hline $\mathrm{C}_{\text {mic }}: \mathrm{C}_{\text {tot }}$ & $0.98 * * *$ & $0.68^{* * *}$ & $0.65^{* * *}$ & $-0.63 * * *$ & 0.30 & 0.27 & -0.37 & $-0.61 * *$ \\
\hline
\end{tabular}




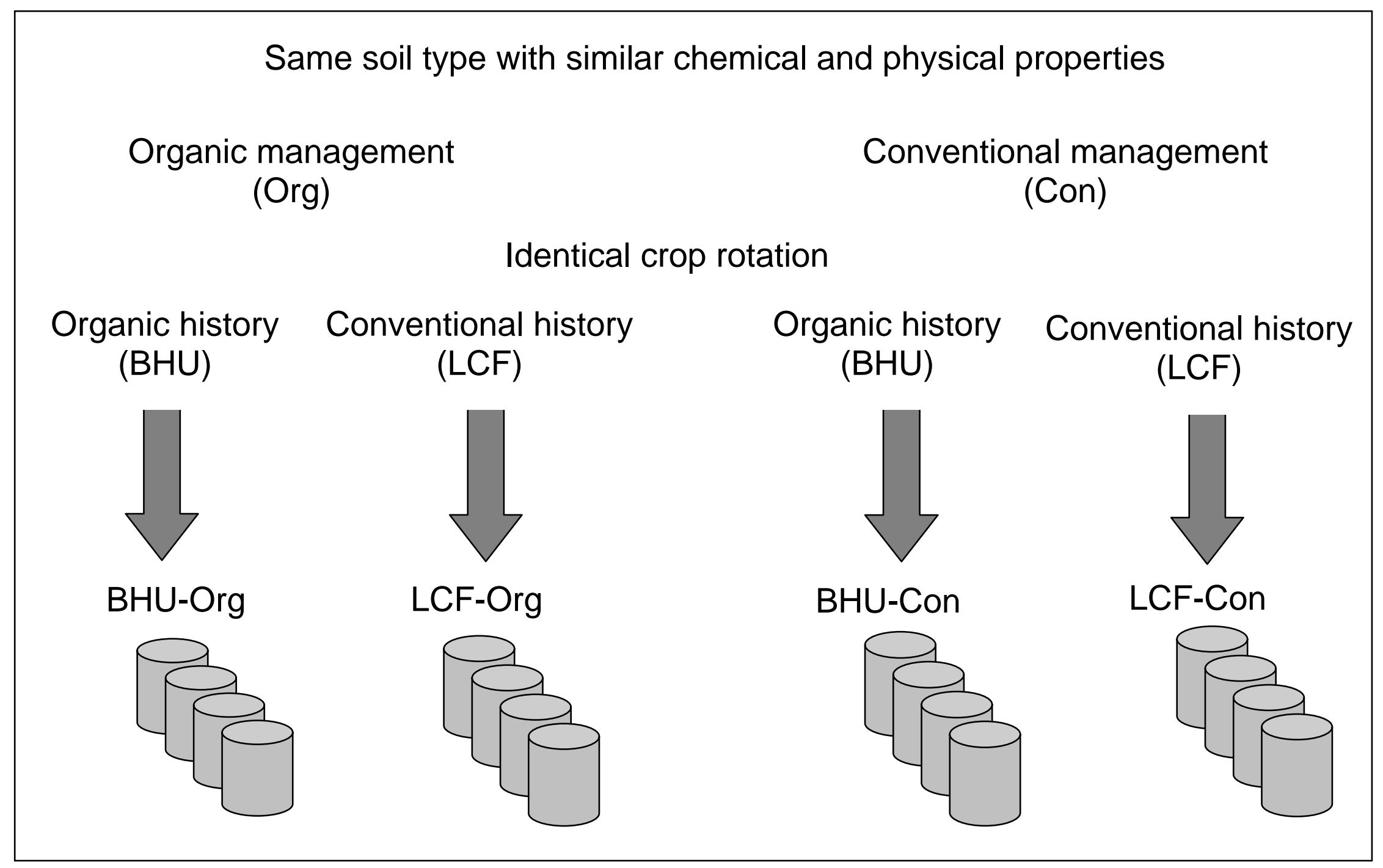

Fig 1 Schematic representation of the lysimeter trial setup 

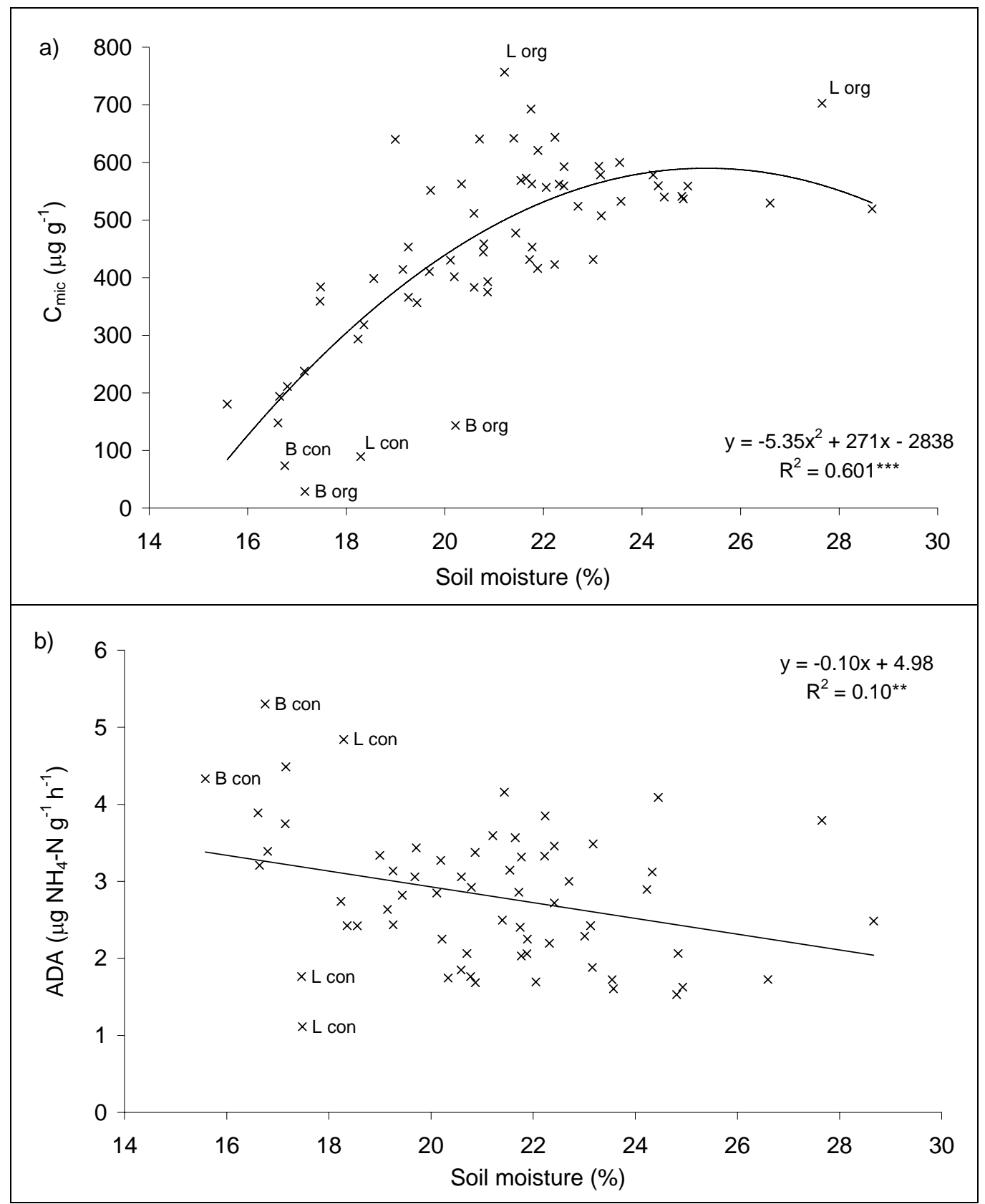

Fig. 2 Relationship of soil moisture content with microbial biomass C (a) and with ADA (b) for the lysimeter soils. Regression equation, line of best fit and statistical significance shown. ${ }^{* *}, \mathrm{p}<0.01$; $* * *, \mathrm{p}<0.001 . \mathrm{n}=64$. 


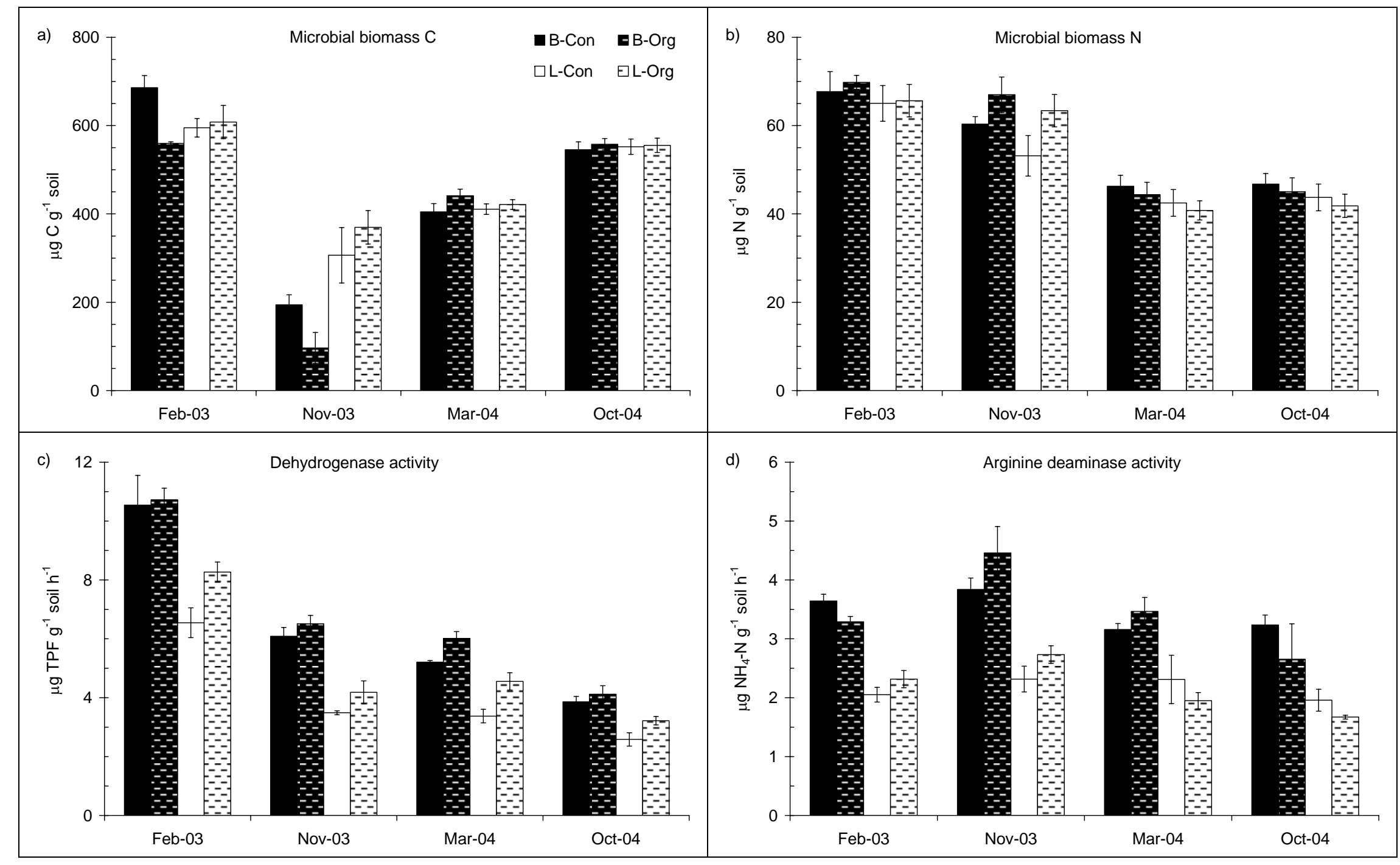

Fig. 3 Mean concentrations $\left(\mu \mathrm{g} \mathrm{g}^{-1}\right)$ of microbial biomass $\mathrm{C}(\mathrm{a})$ and $\mathrm{N}(\mathrm{b})$ and mean rates $\left(\mu \mathrm{g} \mathrm{g}^{-1} \mathrm{~h}^{-1}\right)$ of dehydrogenase hydrolysis (c) and arginine deaminase activity (d) determined in the lysimeter soils at four sampling dates. Bars are standard errors of means. $\mathrm{n}=36$. 


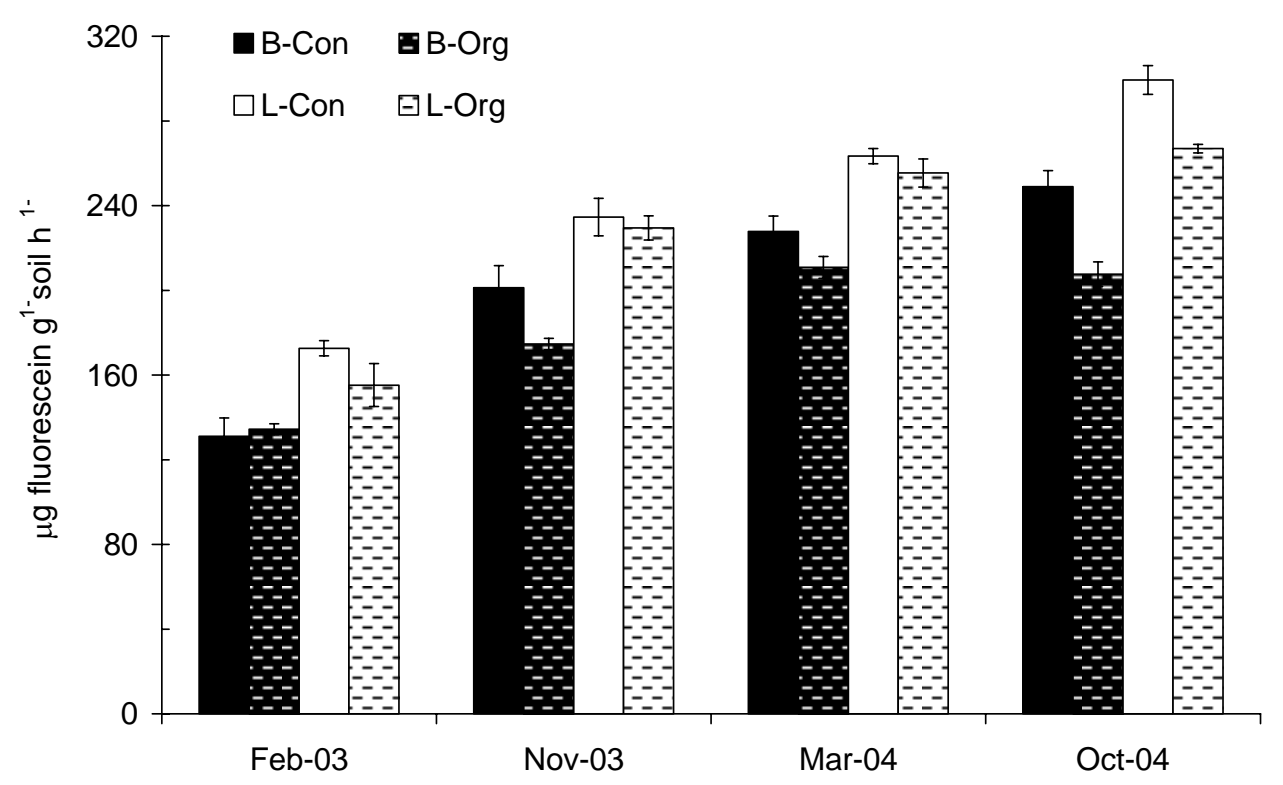

Fig. 4 Mean rate $\left(\mu \mathrm{g} \mathrm{g}^{-1} \mathrm{~h}^{-1}\right)$ of fluorescein diacetate hydrolysis determined in the lysimeter soils at four sampling dates. Bars are standard errors of means. $n=36$. 